\title{
Anti-inflammatory effects of systemic anti-tumour necrosis factor $\alpha$ treatment in human/murine SCID arthritis
}

Hiltrud Schädlich, Jörg Ermann, Maria Biskop, Werner Falk, Frauke Sperling, Astrid Jüngel, Jörg Lehmann, Frank Emmrich, Ulrich Sack nant part in the pathogenesis of rheumatoid arthritis (RA), appearing in a primary position in the cytokine cascade that sequentially activates interleukin 1 (IL1) and interleukin 6 (IL6). ${ }^{1}$ In the RA synovial membrane (SM), $\mathrm{TNF} \alpha$ is predominantly produced by activated macrophages, as shown immunohistochemically. ${ }^{23} \mathrm{TNF} \alpha$ is also expressed at the cartilagepannus junction, ${ }^{4}$ where it is believed to contribute to cartilage and bone destruction. ${ }^{56}$ The clinical relevance of $\mathrm{TNF} \alpha$ in human and experimental arthritis is clearly indicated by the success of systemic application of anti$\mathrm{TNF} \alpha$ antibodies, which cause a rapid improvement of clinical and serological parameters of inflammation. ${ }^{7-9}$ Interestingly, recent studies have shown that anti-TNF treatment in experimental arthritis depends on T cells. ${ }^{10}$

$\mathrm{TNF} \alpha$ can be clearly detected in the arthritic joints of a number of experimental models of arthritis. ${ }^{911-13}$ The pro-inflammatory role of this cytokine is stressed not only by the aggravation of collagen induced arthritis upon administration of exogenous $\mathrm{TNF} \alpha,{ }^{14}{ }^{15}$ but also, and more importantly, by the chronic synovitis that develops after transgenic overexpression of human TNF $\alpha$ in recipient mice. ${ }^{16} 17$ In antigen induced arthritis, furthermore, $\mathrm{TNF} \alpha$ plays a major part in the induction of arthritis, stimulating synovial fibroblasts to express metalloproteinases. Indeed, while synoviocytes isolated from mice with antigen induced arthritis transfer disease when injected into the knee joints of SCID mice, their arthritogenic potential is reduced in TNF knockout mice ( $\mathrm{R}$ Bräuer, Jena, personal communication).

Our group has previously shown that unilateral grafting of human RA-SM into the knee joints of SCID mice induces a lymphocyte independent arthritis in which human and murine inflammatory cells, including macro-
The pro-inflammatory cytokine tumour necrosis factor $\alpha(\mathrm{TNF} \alpha)$ is thought to play a domi-
Immunology Unit, Large Animal Medical Department,

University of Leipzig, Germany

J Lehmann

Correspondence to: Dr U Sack, Institute of Clinical Immunology and Transfusion Medicine, University of Leipzig, Linnéstrasse 3, D-04103 Leipzig, Germany.
Table 1 Number of engrafted mice, characteristics of RA synovial membrane grafts, and therapeutic protocols. Histological classification according to Stiehl (see in Methods ${ }^{20}$; BA: basic activity, AA: actual activity, type III: mixed type with characteristics from type I and type II)

\begin{tabular}{lllll}
\hline Graft & $\begin{array}{l}\text { Histological diagnosis of the } \\
\text { engrafted RA-SM }\end{array}$ & $\begin{array}{l}\text { Number of } \\
\text { engrafted mice }\end{array}$ & $\begin{array}{l}\text { Duration of } \\
\text { experiment (weeks) }\end{array}$ & Treatment \\
\hline RA-SM & RA type III, & 5 & 8 & Rat- $\alpha$-murine TNF $\alpha$ moAb, $120 \mu \mathrm{g}$ ip \\
1 & BA II,AA 0-I & 5 & 8 & Isotype control, $120 \mu \mathrm{g}$ ip \\
RA-SM & RA type III, & 5 & 8 & None \\
2 & BA II, AA II & 5 & 12 & Rat- $\alpha$-murine TNF $\alpha$ moAb, $300 \mu \mathrm{g}$ ip \\
Sham operation & None & 5 & 12 & Isotype control, $300 \mu \mathrm{g}$ ip \\
None & None & 5 & 12 & None \\
& & 5 & 8 & None \\
& & 5 & 8 & None \\
\end{tabular}


Table 2 Histological criteria for the grading of synovitis

\begin{tabular}{|c|c|c|c|c|}
\hline Score & 0 & 1 & 2 & 3 \\
\hline Synovial hyperplasia & None & Limited hyperplasia & Bubble-like hyperplasia & Hyperplasia, inflammatory, infiltration \\
\hline Synovial lining hyperplasia & None & Lining visible but hardly hyperplastic & Single areas of hyperplasia & Diffuse hyperplasia \\
\hline Inflammation around the graft & None & Inflammation under patellar sinew & Inflammation beyond patellar sinew & Marked and diffuse inflammation \\
\hline
\end{tabular}

phages, contribute to synovial inflammation. ${ }^{18}$ Similarly to other experimental arthritides, this model is also expected to be characterised by the expression of $\mathrm{TNF} \alpha$ in the inflamed SM. Based on this assumption, we therefore performed long term anti-TNF $\alpha$ treatment with systemic application (intraperitoneal (ip)) of anti-TNF monoclonal antibodies, to test whether $\mathrm{TNF} \alpha$ neutralisation modulates the course of disease. Systemic and local parameters of disease were evaluated, including cytokine and acute phase protein levels in the serum, as well as inflammatory infiltration and tissue destruction in the joints.

\section{Methods}

HUMAN TISSUE SAMPLES

SM was obtained from RA patients $(\mathrm{n}=2)$ undergoing joint surgery. Both patients fulfilled the 1987 revised ACR criteria. ${ }^{19}$ SM specimens were characterised and classified according to previous studies, ${ }^{20}$ based on basic and actual disease activity (BA and $\mathrm{AA}$, representing immunological, chronic processes and acute inflammatory acitivy, respectively), as well as on: (a) predominant $\mathrm{B}$ cell infiltration without joint destruction features (type I); (b) predominant $\mathrm{T}$ cell infiltration with joint destruction (type II); and (c) mixed B cell and T cell infiltration (type III), with intermediate characteristics of type I and II (for details see table 1).

ANIMALS

SCID mice (C.B.-17/lcrCrl-scid) were purchased as specific pathogen free animals from Charles River WIGA (Sulzfeld, Germany) and kept in a sterile filter cabinet throughout the experiment. Serum IgM was measured by ELISA, as described previously, ${ }^{21}$ to check for incompleteness of the SCID defect. Mice with $>10 \mu \mathrm{g} / \mathrm{ml} \mathrm{IgM}^{22}$ were excluded from further experiments.

TISSUE ENGRAFTMENT

Implantation of human tissue into mice knee joints was as described previously, ${ }^{18}$ via introduction of a small piece of synovial tissue (1 $\mathrm{mm}^{3}$ ) through a lateral incision. The graft was fixed in direct contact with cartilage and the joint cavity closed by surgical suture. Table 1 describes the number of operated mice, the characterisation of the RA-SM samples, and the therapeutic modalities.

Table 3 Monoclonal antibodies used for immunohistochemical staining of murine cells and murine cytokines

\begin{tabular}{llll}
\hline Macrophage & Granulocyte & IL6 & TNFa \\
\hline MoMa-2 & Gr-1 & Rat-antimouse IL6, & Rat-antimouse TNF $\alpha$, \\
Dianova, & Pharmingen, & clone: MP5-20F3, & clone: MP6-XT3, \\
Hamburg, & Hamburg, & Pharmingen, & Pharmingen, \\
Germany & Germany & Hamburg, Germany & Hamburg, Germany \\
\hline
\end{tabular}

THERAPEUTIC ANTI-TNF MONOCLONAL ANTIBODY The rat-antimouse TNF $\alpha$ MoAb V1q (IgD, $\kappa)^{23}$ was used for treatment. In the L929 cytotoxicity assay, $1 \mathrm{ng}$ of purified antibody neutralises $0.25 \mathrm{ng}$ of recombinant murine $\mathrm{TNF} \alpha$, but not recombinant human $\mathrm{TNF} \alpha$ and TNF $\beta$, recombinant human IL1 $\beta$, or recombinant murine IL1. ${ }^{24}$ After ip injection into mice, the antibody can be detected for $>5$ days in the circulation. ${ }^{24}$

The MoAb V1q was administered ip at regular intervals twice weekly throughout the experiment (12 weeks), starting on day 1 after the engraftment of human tissue (see table 1 for details).

\section{MONITORING OF DISEASE PARAMETERS}

foint swelling

The joint diameter of the engrafted knees (consistently the left side) was measured with a calliper and compared with that of age matched SCID mice. Measurements were performed at weekly intervals by the same investigator.

\section{Serum cytokine concentrations}

At $1,3,10,14$, and 28 days after engraftment, blood was withdrawn from the orbital venous plexus. Serum was immediately obtained by centrifugation and stored at $-70^{\circ} \mathrm{C}$ until analysis. Human IL6 was determined using a commercial ELISA kit (R\&D Systems, Wiesbaden, Germany) with a sensitivity of 0.7 $\mathrm{pg} / \mathrm{ml}$. Murine IL6 was measured by a sandwich ELISA, using a rat-antimouse IL6 $\mathrm{MoAb}$ pair (Pharmingen, Hamburg, Germany). MaxiSorb 96 well microtitre plates (Nunc, Wiesbaden, Germany) were coated with antibody (clone: MP5-20F3, $4 \mu \mathrm{g} / \mathrm{ml}$ in carbonate buffer, $\mathrm{pH} 9.6$, overnight, $4^{\circ} \mathrm{C}$ ) and then blocked with phosphate buffered saline (PBS) (pH 7.4; 2\% BSA, 0.01\% Thimerosal) for 30 minutes. Recombinant murine IL6 standard (Endogen, Eching, Germany) or diluted mouse serum $(1: 10)$ were incubated for 12 hours, then a biotinylated antibody (clone: MP5-32C11, $2 \mu \mathrm{g} / \mathrm{m}$ ) was added for six hours at $4^{\circ} \mathrm{C}$. After incubation for 30 minutes with ExtrAvidin-Peroxydase 1:1000 (SigmaAldrich, Deisenhofen, Germany), tetramethylbenzidine (Sigma-Aldrich) was used as substrate. After 90 minutes, $1 \mathrm{~N} \mathrm{HCl}$ was added and the extinction read at $450 \mathrm{~nm}$. All reactants were diluted in assay buffer and incubated at room temperature, except where indicated. Washing steps with PBS and $0.2 \%$ Tween 20 were performed between all incubations. The sensitivity of the assay was determined as 4 $\mathrm{pg} / \mathrm{ml}$.

Murine serum amyloid $P(S A P)$

SAP was measured as described ${ }^{25}$ with some modifications. Microtitre plates were coated with dinitrophenylated keyhole limpet haemo- 

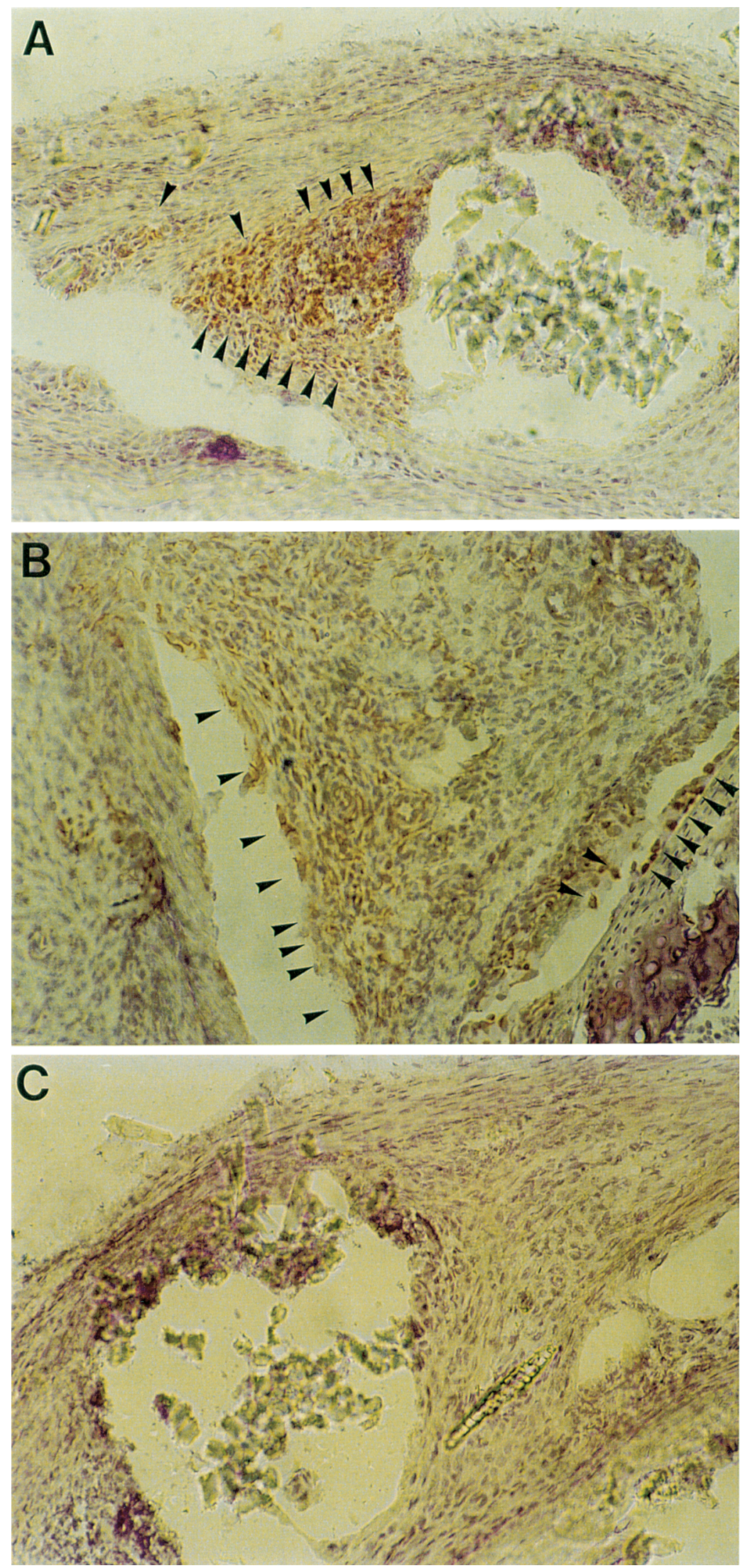

Figure 1 Immunohistochemical staining for $(A)$ murine $T N F a$, original magnification $\times$ 160 , and (B) murine IL6, original magnification $\times 160$, in the knee joint of SCID mice after transplantation of human RA-SM. Cytokine producing cells are stained brown $(A E C)$ and are indicated by arrows. (C) Isotype control (purified rat IgG1, $\kappa$ ), original magnification $\times 160$.
$\mathrm{mM} \mathrm{CaCl} 2,2 \% \mathrm{BSA} ; 0.01 \%$ Thimerosal) for 30 minutes, standard SAP in serial dilution from $2000 \mathrm{ng} / \mathrm{ml}$ to $31.2 \mathrm{ng} / \mathrm{ml}$, and serum 1:1000, were incubated for two hours at room temperature. Bound SAP was detected with rabbit-antimouse SAP (Calbiochem, $0.5 \mu \mathrm{g}$ / $\mathrm{ml}$, two hours, $4{ }^{\circ} \mathrm{C}$ ), peroxydase labelled swine-antirabbit antibody (Dako, Hamburg, Germany) 1:1000, one hour, room temperature) and orthophenyldiamin as substrate. Extinction was read at $492 \mathrm{~nm}$ after addition of $1 \mathrm{~N} \mathrm{Hcl}$.

HISTOLOGY AND IMMUNOHISTOCHMISTRY

Murine knee joints were snap frozen in liquid nitrogen and embedded in $8 \%$ glycerol gelatine (Merck, Darmstadt, Germany). Sagittal cryostat sections of $7 \mu \mathrm{m}$ were cut using a Jung Frigocut (Leica, Bensheim, Germany) and fixed onto transparent tape (Uhu, Bühl, Germany) to prevent disintegration of articular structures. ${ }^{26}$ Sections were air dried and stored at $-70^{\circ} \mathrm{C}$ until staining.

Giemsa staining was performed to allow histopathological analysis of the joints. The degree of hyperplasia of synovial lining layer and sublining, as well as that of the inflammatory infiltration, were scored in a blinded fashion according to the criteria listed in table 2 .

The degree of joint destruction was determined by using a scoring system as described previously. ${ }^{27}$ Briefly, criteria used were cartilage erosion (slight $=1$ ), cartilage destruction with bone erosion (intermediate $=2$ ), and destruction of bone structures (strong=3).

Inflammatory cells were further characterised by immunohistochemistry. For this purpose, the sections were thawed (30 minutes) and fixed (15 minutes) in ice cold paraformaldehyde ( $4 \%$ in phosphate buffer, $\mathrm{pH} 7.4$ ).

Human cells were stained as described previously, using an indirect peroxidase technique. ${ }^{28}$ Cryostat sections were incubated with monoclonal mouse-anti-HLA-ABC W 6/32 (Dako) followed by peroxidase labelled rat-antimouse Ig (Dako) and DAB (SigmaAldrich) as substrate. Counterstaining was performed with haematoxylin (Merck).

The APAAP technique with alkaline phosphatase labelled mouse $\mathrm{F}(\mathrm{ab})_{2}$-antirat Ig (Dianova, Hamburg, Germany) and rat APAAP (Dako) was used to detect murine macrophages and granulocytes; the ABC method with biotin labelled mouse $\mathrm{F}(\mathrm{ab})_{2}$-antirat Ig (Dianova) and StreptAB/ComplexHRP (Dako) was applied to detect murine IL6 and $\mathrm{TNF} \alpha$. Table 3 summarises the primary monoclonal antibodies. Control stainings were performed in parallel with isotype matched Ig (purified rat IgG1, $\kappa$; Pharmingen). Saponin $(0.1 \%)$ was used to detect murine $\mathrm{TNF} \alpha$ intracytoplasmatically, as described previously. ${ }^{29}$ To reduce background signals, blocking was performed using TRIS buffered saline (TBS) with $10 \%$ fetal calf serum, and washing with $0.1 \%$ Tween 20 in TBS. 3-amino-9-ethylcarbazole (AEC Substrat System, Dako) and Fast RedTR/Naphthol AS-MX phosphate (SigmaAldrich) were used as substrates. cyanin (Calbiochem, Bad Soden, Germany) $2.5 \mu \mathrm{g} / \mathrm{ml}$ in carbonate buffer, $\mathrm{pH} 9.6$ overnight at $4^{\circ} \mathrm{C}$. After a blocking step with assay buffer (50 mM TRIS/HCl pH 7.8; $0.15 \mathrm{M} \mathrm{NaCl} ; 5$

P




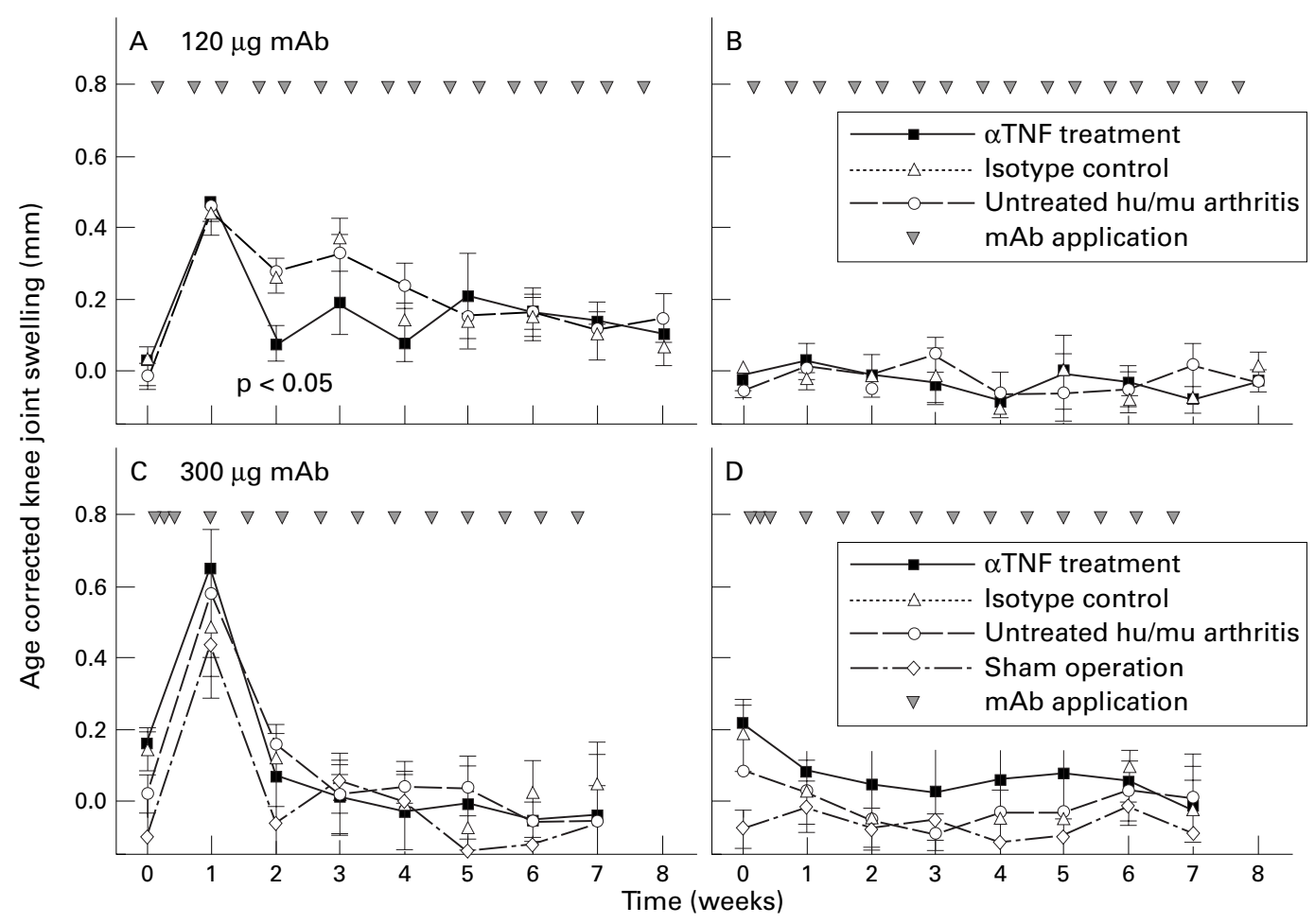

Figure 2 Foint thickness measurement of left and right knee of SCID mice after transplantation of RA-SM I (see table 1 for details) and intraperitoneal application of $120 \mu \mathrm{g}$ anti-murine TNFa MoAb twice a week (A: engrafted knee, B: contralateral knee); or after transplantation of RA-SM II (see table 1 for details) and intraperitoneal application of $300 \mu \mathrm{g}$ monoclonal anti-murine TNFa monoclonal antibody twice a week (C: engrafted knee, D: contralateral knee). The appropriate controls are also shown (treatment with isotype antibody; no treatment; and treatment of sham operated mice). Significant changes are indicated.

STATISTICAL ANALYSIS

Comparisons were performed using the MannWhitney rank sum test. A value of $\mathrm{p}<0.05$ was considered significant. All statistical analyses were performed using SigmaStat for Windows (Jandel Scientific, Erkrath, Germany).

\section{Results}

CYTOKINE EXPRESSION IN THE SYNOVIAL

MEMBRANE OF HU/MU SCID MICE

The expression of murine $\mathrm{TNF} \alpha$, as well as that of IL6, could be demonstrated immunohistochemically in the inflamed knee joints of mice two weeks or one week (respectively) after local engraftment with human RA-SM tissue (fig 1), but not at later time points. Controls performed with isotype Ig were negative. In sham operated animals, neither TNF $\alpha$ nor IL6 were detectable. Because TNF $\alpha$ could not be demonstrated for longer periods, the effects of anti-TNF treatment on $\mathrm{TNF} \alpha$ expression could not be investigated.

EFFECTS OF ANTI-TNF TREATMENT ON CLINICAL AND SEROLOGICAL PARAMETERS OF DISEASE Treatment was performed accordingly to two different study designs (see table 1 for details). In experiment I, mice received $120 \mu \mathrm{g}$ of anti$\mathrm{TNF} \alpha$ monoclonal antibodies twice weekly. This group showed an earlier decline of joint swelling than controls, with a statistically significant difference at two weeks $(\mathrm{p}<0.05$; fig $2 \mathrm{~A}$ and $\mathrm{B}$ ). Although these differences are very subtle, they were shown to be reliable, consistent with previous and current investigations, as well as independent of the operator. In experiment II, TNF neutralisation did not reduce joint swelling despite the high antibody dose used ( $300 \mu \mathrm{g}$; fig $2 \mathrm{C}$ and $\mathrm{D}$ ). We have no explanation for this effect.

To estimate the effects of anti-TNF $\alpha$ treatment on the systemic components of the inflammatory response, the serum concentrations of human and murine IL6 were determined. While human IL6 could not be detected in any of the engrafted animals (data not shown), murine IL6 increased to a peak on day 3 (fig 3A). Interestingly, on this date mice treated with anti-TNF displayed even significantly higher serum IL6 concentrations than controls $(\mathrm{p}<0.05$, fig $3 \mathrm{~A})$. These effects were stronger in the group treated with higher antibody dose.

The other systemic parameter considered was SAP, which, on day 3, was significantly increased in comparison with non-engrafted SCID mice ( $\mathrm{p}<0.05$; (mean (SD) 130 (48) $\mu \mathrm{g} / \mathrm{ml} ; \mathrm{n}=22)$. This increase declined within two weeks. Treatment with high dose antiTNF antibodies (study design II) prevented the SAP rise on day 3 and caused a significantly faster decline of this acute phase protein compared with untreated hu/mu arthritis $(\mathrm{p}<0.05$ at day 3, fig 3B).

\section{EFFECTS OF ANTI-TNF TREATMENT ON} HISTOPATHOLOGICAL PARAMETERS OF DISEASE Untreated hu/mu mice showed prominent macrophage infiltration on day 3 after transplantation (data shown previously ${ }^{30}$ ). Anti-TNF $\alpha$ treatment induced a significant reduction of the inflammatory infiltration ( $\mathrm{p}<0.05$; fig $4 \mathrm{~A})$ and synovial hyperplasia $(\mathrm{p}<0.05$; fig 5$)$. 

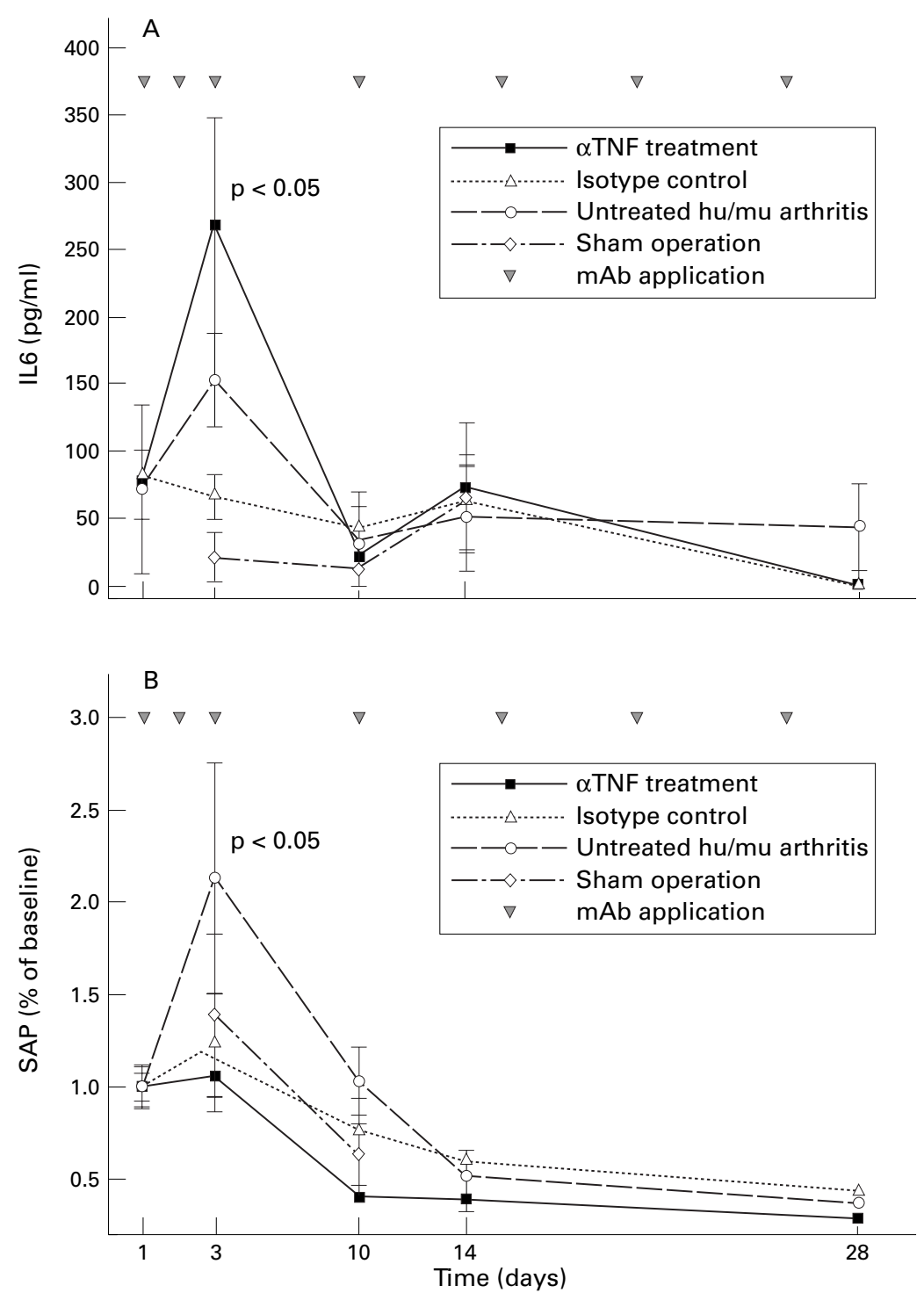

Figure 3 Serum concentrations of murine IL6 (A) and murine SAP (B) after implantation of RA-SM II (see table 1 for details) and administration of $300 \mu \mathrm{g}$ anti-murine TNFa monoclonal antibody as indicated by arrowheads. The appropriate controls are also shown. $p<0.05$ in the comparison between anti-TNF treatment and untreated hu/mu SCID. tory infiltration and synovial hyperplasia. Thus, these data are consistent with the amelioration of arthritis observed in other animal models, for example murine collagen induced arthritis. ${ }^{9} 1131$

Two features are unique to the hu/mu SCID arthritis: (1) the presence of implated (inflamed) human synovial tissue, which may contribute to the host disease by releasing human $\mathrm{TNF} \alpha$. Irrespective of the amounts of $\mathrm{TNF} \alpha$ possibly produced by the human graft (which may reflect in turn the microscopic heterogeneity of the RA samples used for grafting), the release of human $\mathrm{TNF} \alpha$ may not play a considerable part, as the anti-murine antibody did not cross react with human TNF; (2) the lymphocyte independent nature of arthritis (at least in terms of murine lymphocytes), which provides the possibility to examine pathogenetic and/or therapeutic aspects without the influence of specific immunity. In this study, therefore, excluding human inflammatory cells or murine $\mathrm{T}$ lymphocytes as possible TNF source, the disease relevant $\mathrm{TNF} \alpha$ seems to originate predominanty in host activated macrophages.

In vitro experiments have shown that antiTNF antibodies inhibit the production of IL6 and other pro-inflammatory cytokines (for example, IL1, IL8, and GM-CSF) by synovial cells. ${ }^{32}$ Somewhat surprisingly, in hu/mu SCID arthritis the neutralisation of TNF induced an increase of IL6 in the serum, suggesting that this cytokine could exert anti-inflammatory effects. Notably, however, an increase in IL6 was associated also to treatment with the higher, ineffective dose of anti-TNF treatment. Indeed, while IL6 acts as a pro-inflammatory cytokine in some systems, ${ }^{33}$ we have previously shown that the local application of recombinant human IL6 does not increase inflammation in hu/mu SCID arthritis. ${ }^{34}$ In addition, a significant inhibitory effect of IL6 has been demonstrated not only in rat adjuvant arthritis, ${ }^{35}$ but also in zymosan arthritis induced in IL6 deficient mice. ${ }^{36}$ A possible link between IL6 increase and disease amelioration may be the capacity of this cytokine to increase the release of IL1 receptor antagonist, the natural inhibitor of IL1, the latter a central mediator of joint destruction. ${ }^{37}$ Likewise, IL6 may increase the release of soluble TNF receptors, ${ }^{38}$ which, by binding to soluble TNF, neutralises its effects.

In the course of arthritis, acute phase proteins are produced in the liver as part of a systemic, acute inflammatory reaction. While $\mathrm{C}$ reactive protein is the main marker for disease activity in human RA, ${ }^{39} \mathrm{SAP}$ is the main acute phase protein in mice, induced under the influence of IL1 and IL6. ${ }^{40}$ This study indicates that SAP is a useful marker of TNF mediated inflammation, in that TNF neutralisation significantly reduces the rise of this acute phase protein. Also, these early, systemic antiinflammatory effects of anti-TNF treatment clearly precede the clinical amelioration of local synovitis, which occurs not before two weeks in terms of joint swelling (fig 2). 

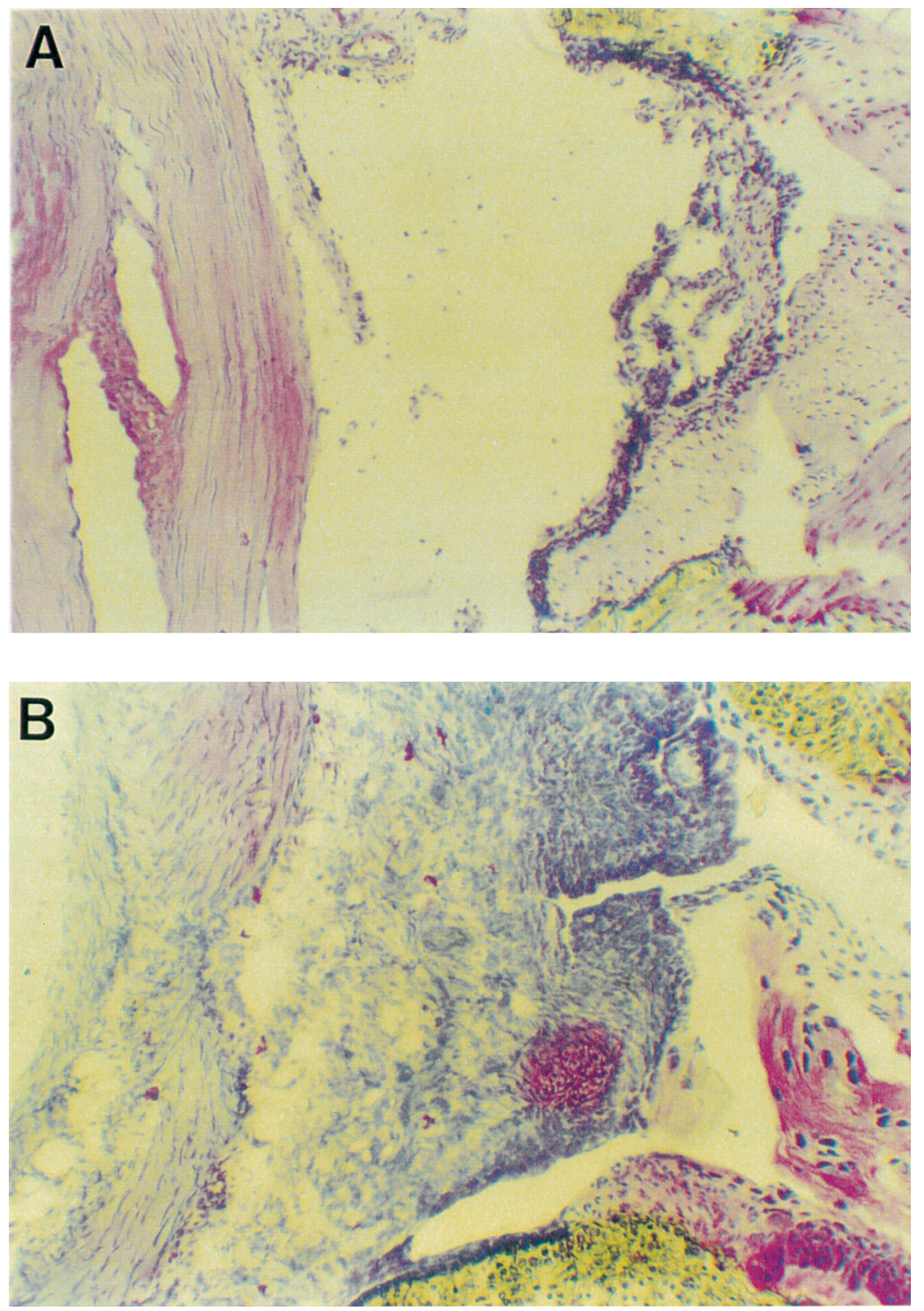

Figure 4 Giemsa staining of cryostat joint section eight weeks after implantation of $R A-S M I$ and $(A)$ treatment with $120 \mu \mathrm{g}$ of anti-murine TNFa antibody twice weekly or (B) isotype control, original magnification $\times 100$. Anti-TNF treatment significantly reduces infiltration of synovial membrane and joint space by murine inflammatory cells, mainly macrophages.

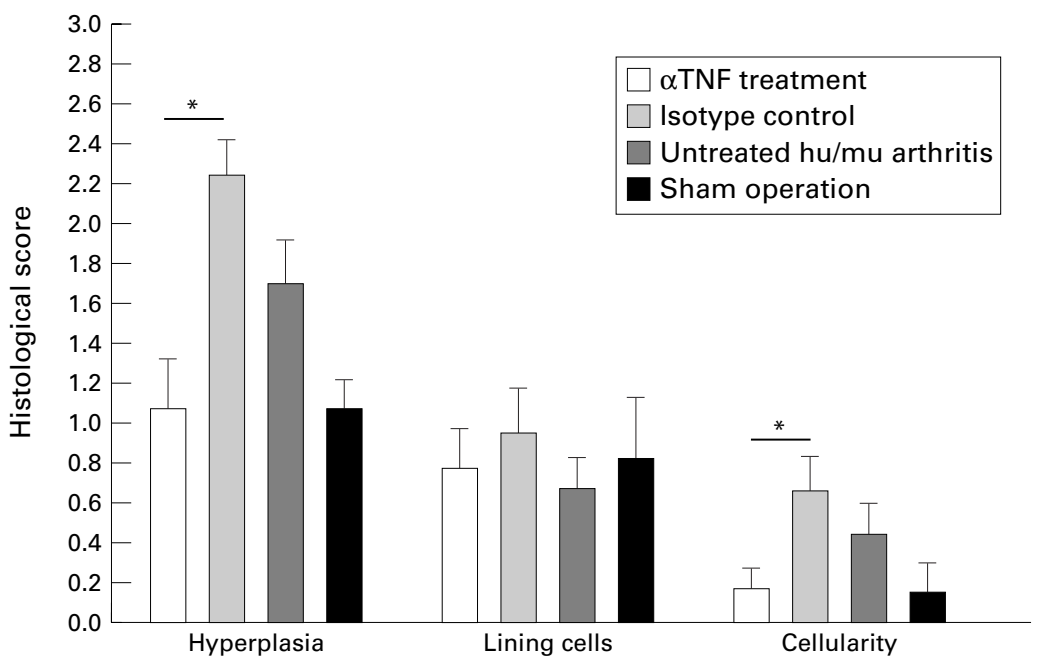

Figure 5 Histological scoring of joint sections eight weeks after implantation of RA-SM I and treatment with anti-murine TNFa (see methods for details). Values are means (SD), ${ }^{\star} p<0.05$ for the comparisons indicated by the bars.
At the same time that SAP is significantly reduced by anti-TNF $\alpha$, the IL6 concentrations in the serum increase, as discussed above. Because IL6 is the main regulator of the acute phase response, this paradoxical increase remains therefore unclear. This paradox seems true in human RA as well, because treatment of severe disease with anti-IL6 monoclonal antibody reduces the $\mathrm{C}$ reactive protein concentrations, however, the clinical improvement is accompanied by increased IL6 concentrations. ${ }^{41}$

Histological analyses showed that anti$\mathrm{TNF} \alpha$ treatment, in addition to inducing a decrease of joint swelling, also reduces inflammatory infiltration and synovial hyperplasia, similar to other arthritides. In contrast with collagen induced arthritis, however, this treatment has no effect on joint destruction because of the rather mild degree of cartilage damage in untreated animals. ${ }^{42-44}$ The limited feasibility of $\mathrm{hu} / \mathrm{mu}$ SCID arthritis to study the antidestructive effects of anti-TNF treatment is somewhat disappointing, as recent studies have shown that application of anti-TNF $\alpha$ antibodies in another model of xenogenic transfer (a graft of human synovium and cartilage into the muscle of SCID mice ${ }^{45}$ ) induces apoptosis in the transferred synovial cells, thereby reducing their destructive capacity on cartilage. As mentioned above, the anti-destructive process may require the mediation of IL1 rather than TNF. ${ }^{37}$ This hypothesis cannot be proved by our results.

In conclusion, in the lymphocyte independent hu/mu SCID arthritis TNF $\alpha$ is involved in inflammatory processes and its neutralisation reduces local and systemic parameters of inflammation.

We thank K Hofman, Institute of Clinical Immunology and Transfusion Medicine, University of Leipzig, for excellent technical work; P Windgassen, (Experimental Medicine Center, University of Leipzig), for animal housing; G Wichmann, Institute of Clinical Immunology and Transfusion Medicine, University of Leipzig, for determining the specificity of anti-TNF $\alpha$ monoclonal antibodies; P Stiehl, Institute of Patholany and R W Kinne, Institute of Clinical Immunology and ogy and $R$ Wrine, Iniversity of Leipzig for topathological examinations and helpful discussions; and E Palombo-Kinne for critical modification of the manuscript.

Funding: this study was supported by the Federal Ministry of Education, Science, Research, and Technology (grant 01ZZ9103); the Interdisciplinary Center for Clinical Research at the University of Leipzig (grant 01KS9504 A3); the German Research Council (DFG); and the Alexander von Humboldt Foundation (Bonn, Germay).

1 Feldmann M, Brennan FM, Maini RN. Role of cytokines in rheumatoid arthritis. Annu Rev Immunol 1996;14:397-40. Husby G, Williams RC. Synovial localization of tumor necrosis factor in patients with rheumatoid arthritis. J necrosis factor in patients

3 Gräfe H, Stiehl P. Untersuchungen zu Vorkommen und Verteilung von TNF-alpha und TNF-beta in Synovialmembran (SM) von Patienten mit Rheumatoider vialmembran (SM) von Patienten mit Rheumatoider Arthritis (RA)

1994;53:43. [Abstract]. Z Zellforsch Mikrosk Anat

Chu CQ, Field M, Allard S, Abney E, Feldmann M, Maini RN. Detection of cytokines at the cartilage/pannus junction in patients with rheumatoid arthritis: implications for the role of cytokines in cartilage destruction and repair. $\mathrm{Br} J$ Rheumatol 1992;31:653-61.

5 Saklatvala J. Tumour necrosis factor alpha stimulates resorption and inhibits synthesis of proteoglycan in cartilage. Nature 1986;322:547-9.

6 Alsalameh S, Kalden JR, Burmester GR. The role of cytokines and growth factors in rheumatoid joint destruccytokines and growth factors in rhe

7 Feldmann M, Elliott MJ, Brennan FM, Maini RN. Use of anti-tumor necrosis factor antibodies in rheumatoid arthritis. J Interferon Res 1994;14:299-300.

8 Rankin EC, Choy EH, Kassimos D, et al. The therapeutic effects of an engineered human anti-tumour necrosis factor 
alpha antibody (CDP571) in rheumatoid arthritis. Br J Rheumatol 1995;34:334-42.

9 Marinova-Mutafchieva L, Williams RO, Mason LJ, Mauri C, Feldmann M, Maini RN. Dynamics of proinflammatory cytokine expression in the joints of mice with collageninduced arthritis (CIA). Clin Exp Immunol 1997;107: 507-12.

10 Williams RO, Mauri C, Mason LJ, et al. Therapeutic actions of cyclosporine and anti-tumor necrosis factor alpha in collagen-induced arthritis and the effect of combination therapy. Arthritis Rheum 1998;41:1806-12.

11 Mussener A, Litton MJ, Lindroos E, Klareskog L. Cytokine production in synovial tissue of mice with collagen-induced production in synovial tissue of mice with collagen-ind

12 Lewthwaite J, Blake S, Hardingham T, et al. Role of TNF alpha in the induction of antigen induced arthritis in the rabbit and the anti-arthritic effect of species specific TNF alpha neutralising monoclonal antibodies. Ann Rheum Dis 1995; 54:366-74

13 Beech JT, Thompson SJ. Anti-tumour necrosis factor therapy ameliorates joint disease in a chronic model of inflammatory arthritis. [Letter]. Br J Rheumatol 1997;36: 1129

14 Cooper WO, Fava RA, Gates CA, Cremer MA, Townes AS Acceleration of onset of collagen-induced arthritis by intra-articular injection of tumour necrosis factor or transforming growth factor-beta. Clin Exp Immunol 1992;89: 244-50.

15 Brahn E, Peacock DJ, Banquerigo ML, Liu DY. Effects of tumor necrosis factor alpha (TNF-alpha) on collagen arthritis. Lymphokine and Cytokine Research 1992;11: 253-6.

16 Keffer J, Probert L, Cazlaris $\mathrm{H}$, et al. Transgenic mice expressing human tumour necrosis factor: a predictive genetic model of arthritis. EMBO J 1991;10:4025-31.

17 Butler DM, Malfait AM, Mason LJ, et al. DBA/1 mic expressing the human TNF-alpha transgene develop a severe, erosive arthritis: characterization of the cytokine cascade and cellular composition. J Immunol 1997;159: 2867-76.

18 Sack U, Kuhn H, Ermann J, et al. Synovial tissue implants from patients with rheumatoid arthritis cause cartilage destruction in knee joints of SCID.bg mice. J Rheumatol 1994;21:10-16.

19 Arnett FC, Edworthy SM, Bloch DA, et al. The American Rheumatism Association 1987 revised criteria for the classification of rheumatoid arthritis. Arthritis Rheum 1988; 31:315-24.

20 Stiehl P. Histologie der Rheumatoid-Arthritis. Beitrag zur diagnostischen und pathogenetischen Heterogenität, zur Aktivitätsdiagnose und zur Prognose. In: Sack U, ed. Arthritiden. Lengerich: Pabst Science Publishers, 1997: 188-200.

21 Kuhn H, Ermann J, Sack U. Modulation of hu/mu severe combined immunodeficient (SCID) mouse arthritis by local application of human recombinant IL-1beta, IL- 2 and IL-6. Clin Exp Immunol 1997;107:96-102.

22 Bosma GC, Fried M, Custer RP, Carroll A, Gibson DM, Bosma MJ. Evidence of functional lymphocytes in some (leaky) scid mice. J Exp Med 1988;167:1016-33.

23 Kojouharoff G, Hans W, Obermeier F, et al. Neutralization of tumour necrosis factor (TNF) but not of IL-1 reduces inflammation in chronic dextran sulphate sodium-induced inflammation in chronic dextran sulphate sodium-in

24 Echtenacher B, Falk W, Mannel DN, Krammer PH Requirement of endogenous tumor necrosis factor/ cachectin for recovery from experimental peritonitis. J Immunol 1990;145:3762-6.

25 Serban D, Rordorf-Adam C. Quantitation of serum amyloid $\mathrm{P}$ component by an enzyme-linked immunoassay. J Immunol Methods 1986;90:159-64.

26 Rijntjes NV, van de Putte LB, van der Pol M, Guelen PJ. Cryosectioning of undecalcified tissues for immunofluorescence. J Immunol Methods 1979;30:263-8.
27 Sack U, Kuhn H, Kampfer I, et al. Orthotopic implantation of inflamed synovial tissue from RA patients induces a characteristic arthritis in immunodeficient (SCID) mice. J Autoimmun 1996;9:51-8.

28 Sack U, Kuhn H, Ermann J, et al. Synovial tissue implants from patients with rheumatoid arthritis cause cartilage destruction in knee joints of SCID.bg mice. J Rheumatol 1994; 21:10-16.

29 Ulfgren AK, Lindblad S, Klareskog L, Andersson J, Andersson U. Detection of cytokine producing cells in the tis. Ann Rheum Dis 1995;54:654-61.

30 Sack U, Kuhn H, Kampfer I, et al. Orthotopic implantation of inflamed synovial tissue from RA patients induces a characteristic arthritis in immunodeficient (SCID) mice. J Autoimmun 1996;9:51-8.

31 Williams RO, Feldmann M, Maini RN. Anti-tumor necrosis factor ameliorates joint disease in murine collageninduced arthritis. Proc Natl Acad Sci USA 1992;89: 9784-8.

32 Brennan FM, Chantry D, Jackson A, Maini RN, Feldmann M. Inhibitory effect of TNF alpha antibodies on synovial cell interleukin- 1 production in rheumatoid arthritis. Lancet 1989 ;ii: $244-7$.

33 Hirano T. Interleukin-6 and its relation to inflammation and disease. Clin Immunol Immunopathol 1992;62:S6-5

34 Kuhn H, Ermann J, Sack U. Modulation of hu/mu severe combined immunodeficient (SCID) mouse arthritis by local application of human recombinant IL-1beta, IL- 2 and IL-6. Clin Exp Immunol 1997;107:96-102.

35 Mihara M, Ikuta M, Koishihara Y, Ohsugi Y. Interleukin 6 inhibits delayed-type hypersensitivity and the development inhibits delayed-type hypersensitivity and the development
of adjuvant arthritis. Eur J Immunol. 1991;21:2327-31.

36 Van De Loo FA, Kuiper S, van Enckevort FH, Arntz OJ, van den Berg WB. Interleukin-6 reduces cartilage destruction during experimental arthritis. A study in interleukin-6deficient mice. Am J Pathol 1997;151:177-91.

37 van Lent PL, Van De Loo FA, Holthuysen AE, van den Bersselaar LA, Vermeer H, van den Berg WB. Major role for interleukin 1 but not for tumor necrosis factor in early cartilage damage in immune complex arthritis in mice. J Rheumatol 1995;22:2250-8

38 Tilg H, Trehu E, Atkins MB, Dinarello CA, Mier JW. Interleukin-6 (IL-6) as an anti-inflammatory cytokine:
induction of circulating IL-1 receptor antagonist and soluble tumor necrosis factor receptor p 55 . Blood 1994;83: 113-18.

39 Emery P, Luqmani R. The validity of surrogate markers in rheumatic disease. Br J Rheumatol 1993;32 (suppl 3):3-8. 40 Le PT, Mortensen RF. Induction and regulation by monokines of hepatic synthesis of the mouse serum amyloid P-component (SAP). J Immunol 1986;136:2526-33.

41 Wendling D, Racadot E, Wijdenes J. Treatment of severe rheumatoid arthritis by anti-interleukin 6 monoclonal antibody. J Rheumatol 1993;20:259-62.

42 Thorbecke GJ, Shah R, Leu CH, Kuruvilla AP, Hardison AM, Palladino MA. Involvement of endogenous tumor necrosis factor alpha and transforming growth factor beta during induction of collagen type II arthritis in mice. Proc Natl Acad Sci USA 1992;89:7375-9.

43 Piguet PF, Grau GE, Vesin C, Loetscher H, Gentz R, Lesslauer W. Evolution of collagen arthritis in mice is arrested by treatment with anti-tumour necrosis factor (TNF) antibody or a recombinant soluble TNF receptor. (TNF) antibody or a recombinar

44 Issekutz AC, Meager A, Otterness IG, Issekutz TB. The role of tumour necrosis factor-alpha and IL-1 in polymorphonuclear leucocyte and $\mathrm{T}$ lymphocyte recruitment to join inflammation in adjuvant arthritis. Clin Exp Immuno 1994;97:26-32.

45 Nezuka T, Matsuno H, Uzuki M, Saeki Y, Tsuji H. Inhibitory effects of TNF-alpha in engraftment of RA synovium into SCID mouse models. [Abstract]. Arthritis Rheum 1997;40 (suppl):S79. 